\title{
EXPLANATORY NOTES \\ ON AID-FOR-TRADE COUNTRY PROFILES
}

The aid-for-trade country profiles provide factual information to stimulate a debate on trends of aid for trade, trade costs, trade performance and development at the country level. The aim is to compare a country's performance in four categories of indicators from 2006 to 2017 and, for selected indicators, against country group benchmarks.

The country profiles are structured according to the results chain framework normally used in project-based development interventions. The results chain framework describes the causal sequence of development interventions based on four main elements: i) inputs and activities produce ii) direct outputs, which in turn lead to iii) intermediate outcomes that contribute to iv) long-term impacts.

The country profiles transpose the idea behind this project-based analytical tool to the macro level and trace a possible causal sequence of aid-for-trade interventions to achieve trade and development objectives. The country profiles therefore present indicators in four sections: A. Development Finance; B. Trade Costs; C. Trade Performance; and D. Development Indicators. Much of aid for trade is aimed at reducing trade costs; lower trade costs increase connectivity and lead to better trade performance in terms of growth and diversification; better trade performance can help improve long-term development indicators, notably through employment creation and poverty alleviation.

The country profiles do not posit a causal link; they do not attempt to test or estimate the causal impact of aid for trade at the macro level. Instead, they give a dynamic perspective on a country's development. In this sense, the sequence traced is one of contribution, not attribution. Where such contribution can be discerned, the country profiles provide ground for further in-depth, country-based research. In this sense, the country profiles contribute to a greater understanding of the important role that aid-for-trade flows play in a country's achievement of the trade and development objectives targeted by these flows.

Most indicators in the country profiles provide a comparison between 2006 and 2017. However, the year coverage is adapted to data availability at the level of both indicators and countries. For a selected number of indicators, comparisons against benchmark groups are shown. The country groups used as benchmarks are least developed countries (LDCs), lower middle income countries (LMICS), upper middle income countries (UMICS) and high income countries (HICs) based on the current United Nation's list of LDCs and the World Bank's income group classification for 2017. The country groups are non-overlapping, which means that LDCs are not included in income groups. Tajikistan and Zimbabwe, which are low income countries but not LDCs, are benchmarked against LMICs. The country composition of the four country groups differs among indicators according to data availability. The number of countries included in the four groups for a given indicator is provided in the indicator descriptions below.

The country profiles are divided into the following four sections:

\section{A. DEVELOPMENT FINANCE}

Development finance constitutes a vital source of external financing for many developing countries as it comprises inflows of foreign direct investment (FDI), remittances, official development assistance (ODA), and other official flows (OOF). Development finance is used to finance capital investment as well as private and public consumption, which thereby forms the basis for economic growth and development.

This section illustrates how aid-for-trade flows have developed over time, how important they are compared to other flows of development finance and the importance of aid-for-trade for a country compared to other countries. Furthermore, the section shows trends in aid-for-trade disbursements over time at the aggregate level and at the level of sectors and donors. Development finance flows are presented for the periods 2006/08 and 2014/16 (three year averages) and for the year 2017. 


\section{Indicators and sources}

FDI is defined as an investment involving a long-term relationship and reflecting a lasting interest in and control by a resident entity in one economy (foreign direct investor or parent enterprise) of an enterprise resident in a different economy (foreign affiliate). FDI inflows measure the net capital (equity capital, reinvested earnings and intra-company loans) provided by a foreign direct investor to a foreign affiliate. Source: UNCTAD, UNCTADstat.

Remittances comprise personal transfers and compensation of employees. Personal transfers consist of transfers in cash or in kind received by resident households from non-resident households. Compensation of employees refers to the income of border, seasonal, and other short-term workers who are employed in an economy where they are not resident and of residents employed by non-resident entities. Compensation of employees tends to account for a high share of remittances in the case of developing countries which are close to a bigger economy such as Lesotho, which borders South Africa, or which are characterised by the presence of non-resident institutions such as Afghanistan. Source: World Bank (WB), World Development Indicators.

Official development assistance (ODA) are grants and loans provided by the official sector with the main objective to promote economic development and welfare of developing countries. ODA is concessional in character with a grant element of at least 25 percent (calculated at a discount rate of 10 percent). Aid-for-trade flows are a subset of ODA that fall under the four categories trade policy and regulations, economic infrastructure, building productive capacity and trade-related adjustment. ODA and aid-for-trade flows are reported as gross disbursements. Source: OECD, DAC-CRS Aid Activities Database.

Other official flows (OOF) are transactions by the official sector which do not meet the conditions for eligibility as ODA, either because they are not primarily aimed at development, or because they have a grant element of less than 25 percent. Trade-related OOF are a subset of OOF that fall under the four categories trade policy and regulations, economic infrastructure, building productive capacity and trade-related adjustment. OOF and trade-related OOF flows are reported as gross disbursements. Source: OECD, DAC-CRS Aid Activities Database.

The top three aid-for-trade priorities are based on a ranking of aid-for-trade categories given by countries in selfassessment questionnaires. Source: OECD/WTO Partner Country Questionnaire.

Share of aid for trade in development finance indicates a country's dependence on aid for trade in comparison to other development finance flows. Development finance corresponds to the sum of FDI inflows, remittances, OOF and ODA. For the periods 2006-08 and 2014-16, development finance is calculated as the sum of the three year averages of these four flows. Number of countries included in benchmark groups: LDCs (36), LMICs (25), UMICs (42). Sources: OECD, DAC-CRS Aid Activities Database; UNCTAD, UNCTADstat; WB, World Development Indicators.

Share of aid for trade in gross fixed capital formation indicates the importance of aid for trade for the financing of gross fixed capital formation. Gross fixed capital formation includes land improvements; plant, machinery, and equipment purchases; and the construction of roads, railways, and the like, including schools, offices, hospitals, private residential dwellings, and commercial and industrial buildings. Number of countries included in benchmark groups: LDCs (29), LMICs (26), UMICs (35). Sources: OECD, DAC-CRS Aid Activities Database; WB, World Development Indicators. 


\section{B. TRADE COSTS}

In the results chain, inputs and accompanying activities result in outputs. One of the main objectives of aid-fortrade projects is to reduce trade costs. The trade costs section covers indicators that allow assessing how a country's infrastructure and policy-related trade costs have evolved over time and how high trade costs are in comparison to a benchmark country group.

\section{Indicators and sources}

Tariffs: Simple and weighted averages of applied import tariffs measure most-favoured-nation (MFN) applied duties calculated either as simple average or as weighted average using import flows at the Harmonized System (HS) sixdigit level as weights. The weighted average export tariff faced takes into account preferences and measures the weighted average tariff faced by the country in its top five export markets for agricultural and non-agricultural products, respectively. The share of duty-free exports measures the share of exports reaching these top export markets for agricultural and non-agricultural products duty-free. Source: WTO, World Tariff Profiles.

Information and Communication Technology (ICT) connectivity (\% of population): Mobile (fixed) broadband subscriptions refer to the percentage of inhabitants with an active mobile (fixed) broadband subscription. Internet users refer to the percentage of the population using the internet. Source: ITU, World Telecommunication/ICT Indicators.

Cost and time to trade measure the cost in USD and the time in hours required for documentary and border compliance when an economy imports a standardized shipment of auto parts from its natural import partner or when the economy exports its most important product in value terms (except oil and mining products) to its natural export partner. Documentary compliance captures the cost and time associated with compliance with the documentary requirements of all government agencies of the origin economy, the destination economy and any transit economies. Documentary compliance includes the cost and time for obtaining, preparing, processing, presenting and submitting documents. Border compliance captures the cost and time associated with compliance with the economy's customs regulations and with regulations relating to other mandatory border inspections, for instance regarding sanitary and phytosanitary standards, as well as the cost and time for handling that takes place at its port or border. Number of countries included in benchmark groups: LDCs (44), LMICs (31), UMICs (51), HICs (58). Source: WB, Doing Business.

Logistics performance index (LPI) (1-5): The "Overall LPI" is a perception-based composite indicator of a country's logistics based on six components. These components are efficiency and border clearance ("Customs"), quality of trade and transport infrastructure ("Infrastructure"), ease of arranging competitively priced shipments ("International shipments"), competence and quality of logistics services ("Logistics competence"), ability to track and trace consignments ("Tracking and tracing") and frequency with which shipments reach consignees within scheduled or expected delivery times ("Timeliness"). The index and its components range from 1 to 5, with a higher score representing better performance. Number of countries included in benchmark groups: LDCs (39), LMICs (25), UMICs (41), HICs (51). Source: WB, Logistics Performance Index.

Competitiveness indicators (1-7): The competitiveness indicators measure the perceptions of business executives regarding the access to finance of SMEs, the efficiency of train services, the quality of roads, the efficiency of seaport services, the efficiency of air transport services and the competition in network services. The ratings range from 1 (low) to 7 (best). Number of countries included in benchmark groups: LDCs (27), LMICs (25), UMICs (34), HICs (52). Source: WEF, Global Competitiveness Report 2018. 
Trade costs (ad valorem, \%): These indicators capture a country's total, intra-regional and extra-regional ad-valorem trade costs in percent. The trade costs measures are calculated as simple averages of bilateral ad valorem trade costs. Given the limited data availability, the number of partners used in the calculation of average trade costs differs across countries. Therefore, the measure is informative regarding a country's evolution of trade costs over time but comparisons between countries should be undertaken with much caution. The bilateral trade costs are derived from observable trade flows representing the geometric mean of international trade costs between two countries relative to domestic trade costs within each country. The intuition of the measure is that if bilateral trade increases relative to domestic trade flows, bilateral trade costs have declined. The database and the bilateral trade cost measure are described in Arvis et al. (2013). To calculate intra- and extra-regional trade costs, trading partners are grouped according to the WTO classification into the following regions: Africa, Asia, Commonwealth of Independent States (CIS), Europe, Middle East, North America, South and Central America (including the Caribbean). Source: Author's calculations based on the ESCAP/World Bank Trade Cost Database.

Trade facilitation indicators (0-2): The trade facilitation indicators are composite indicators that measure various dimensions of trade facilitation, most of them closely related to the WTO Trade Facilitation Agreement, on a range from 0 (low) to 2 (best). The country profiles show the following six indicators (out of a total of eleven) for which data coverage is best: Information availability (publication of trade information, including on internet; enquiry points), Advance rulings (prior statements by the administration to requesting traders concerning the classification, origin, valuation method, etc., applied to specific goods at the time of importation; the rules and process applied to such statements), Appeal procedures (the possibility and modalities to appeal administrative decisions by border agencies), Automation (electronic exchange of data; automated border procedures; use of risk management), Procedures (streamlining of border controls; single windows; post-clearance audits; authorised economic operators), Governance and impartiality (customs structures and functions; accountability; ethics policy). Number of countries included in benchmark groups: LDCs (36), LMICs (28), UMICS (43), HICs (54). Source: OECD Trade Facilitation Indicators.

\section{TRADE PERFORMANCE}

Aid for trade interventions aim at improving the trade performance of firms and countries by addressing national supply side constraints to either lower trade costs or improve the productive capacity of firms. This section covers indicators that allow assessing the trade performance of countries in terms of value, growth, structure and diversification.

\section{Indicators and sources}

Trade to GDP ratio is estimated as an economy's total trade of goods and commercial services (exports + imports, balance of payments basis) divided by its GDP. Source: WTO Secretariat.

Commercial services as \% of total exports (imports) refers to the share of commercial services in world exports (imports) of commercial services and goods. Trade flows are measured by balance of payments statistics according to the principles of the sixth edition of the Balance of Payments Manual (BPM6). Source: WTO Secretariat.

Non-fuel intermediates (\% of merchandise exports [imports]) refers to the share of non-fuel intermediate goods in merchandise exports (imports) as measured by customs statistics. Intermediates are classified according to the UN Broad Economic Categories (BEC) classification. Fuel products are not classified as intermediates but are included in total merchandise exports. Source: UN Comtrade.

Trade flows (billion current US\$) provide exports and imports of goods and commercial services as measured by balance of payment statistics according to the principles of BPM6. Balance of payment statistics cover transactions between residents of a country and non-residents involving a change of ownership. Source: WTO Secretariat. 
Number of products and markets: The numbers of exported and imported products and the numbers of export and import markets provide simple measures of product and market diversification, respectively. The maximum number of markets is 237 while the maximum number of products, defined at the Harmonized System (HS) 2002 4-digit level, is 1,245. Source: Author's calculations based on UN Comtrade data.

Hirschman-Herfindahl $(\mathrm{HH})$ concentration indices: The HH concentration indices measure the concentration, or diversification, of a country's trade in terms of either products or markets. The HH export (import) product concentration index is calculated as the sum of squared product shares in a country's exports (import) and then normalised to lie between zero and one. $\mathrm{HH}$ market concentration indices are calculated analogously. $\mathrm{HH}$ export and import product concentration indices with scores close to zero indicate a diversified, i.e. equally distributed, product portfolio and scores close to one indicate high concentration on a few products. Analogously, in the case of $\mathrm{HH}$ indices of export and import market concentration scores close to zero indicate that trade is diversified, i.e. equally distributed, across markets and scores close concentration on a few markets. It should be noted that the HH indices inform only about the distribution of trade but not about the underlying numbers of products and markets. The assessment of, for instance, export diversification should therefore take into account both the number of exported products and export markets and the $\mathrm{HH}$ indices indicating how equally distributed trade is across these products and markets. Source: Author's calculations based on UN Comtrade data.

Structure of merchandise trade provides a breakdown of merchandise exports and imports by main commodity groups according to the WTO International Trade Statistics (ITS) definitions: agricultural products refer to food (SITC Rev. 3 sections 0, 1, 4 and division 22) and raw materials (SITC Rev. 3 divisions 21, 23, 24, 25 and 26). Fuels and mining products include ores and other minerals; fuels and non-ferrous metals. Manufactures refer to iron and steel, chemicals, other semi-manufactures, machinery and transport equipment, textiles, clothing and other consumer goods. Shares sum up to 100 percent since trade flows that are not classified in any of those product groups, for instance non-monetary gold, are not taken into account in the calculation. Source: WTO Secretariat.

Structure of services trade shows the shares of travel services, transport services, goods-related services and other commercial services in commercial services exports and imports. Goods-related services, inter alia, include manufacturing activities on a contract basis such as processing, assembly, labelling and packing ("manufacturing services on physical inputs owned by others"). Other commercial services refer to communication, construction, insurance, financial, computer, information, other business, and cultural and recreational services, and royalties and license fees. Services trade is measured by balance of payments statistics according to the principles of BPM6. Source: WTO Secretariat.

Top 5 markets for merchandise exports and imports (\%) indicate a country's top five export and import markets as recorded by customs-based statistics. Trade shares with EU member states are shown at the national level according to the national concept, which can deviate from data harmonized according to the community concept. Unspecified origins or destinations (areas n.e.s., bunkers and free zones) are not shown if they are among the top 5 markets. Source: UN Comtrade.

Top 5 merchandise imports and exports (\%) refer to the percentage shares of a country's top five export and import products as recorded by customs-based statistics. Products are measured in terms of the Standard International Trade Classification, Rev.3 (SITC Rev. 3). Source: UN Comtrade. 


\section{DEVELOPMENT INDICATORS}

Aid for trade eventually aims to achieve long-term development impacts through increased participation of countries in international trade. This section describes trends in development indicators related to human and economic development, including poverty and inequality.

\section{Indicators and sources}

Unemployment (\% of total labour force) refers to the share of the labour force that is without work but available for and seeking employment. The unemployment rates are harmonized estimates of the International Labour Organization (ILO) allowing comparisons across countries and over time. Source: ILO, ILOSTAT.

Female labour force participation rate (\%) captures to what extent women participate in the labour market. The indicator measures the proportion of a country's female population aged 15 and older that engages actively in the labour market, either by working or looking for work. Source: ILO, ILOSTAT.

ODA (\% of gross national income): The share of net ODA in gross national income (GNI) indicates to what extent a country is dependent on development assistance. Source: OECD, DAC-CRS Aid Activities Database.

Import duties collected (\% of tax revenue): The share of import duties in tax revenue indicates to what extent a country is dependent on import duties in order to finance its government budget. Source: WB, World Development Indicators.

Total debt service (\% of total exports): Total debt service is the sum of principal repayments and interest paid on longterm debt, interest paid on short-term debt, and repayments (repurchases and charges) to the IMF. Both public and private external debt is included. External indebtedness affects a country's creditworthiness and investor perceptions. The share of total debt service to total exports helps assess the sustainability of a country's debt service obligations, in particular regarding a countries' ability to obtain foreign exchange through exports. Source: WB, World Development Indicators.

Human Development Index (HDI): The HDI ranges from zero (minimum level of development) to one (maximum level of development) summarising the three basic development dimensions health, education and living standard. Source: United Nations Development Programme (UNDP), International Human Development Indicators: Human Development Index.

GDP per capita, PPP (constant 2011 international \$): GDP per capita is converted to international dollars using purchasing power parity rates. An international dollar has the same purchasing power over GDP as the U.S. dollar has in the United States. Number of countries included in benchmark groups: LDCs (43), LMICs (31), UMICs (51), HICs (61). Source: WB, World Development Indicators.

Economic structure: The development of a country's economic structure is captured by the shares of agriculture, industry and services in GDP in 2006 and 2017. Source: WB, World Development Indicators.

Poverty: Population living below $\$ 1.90(\$ 3.20)$ a day measures the percentage of the population living on less than $\$ 1.90$ (\$3.20) a day at 2011 international prices. Source: WB, World Development Indicators.

Inequality: Income held by lowest $20 \%$ (40\%) is the percentage share of income that accrues to the subgroups of population indicated by the respective quintiles. Source: WB, World Development Indicators.

\section{Legend:}

"_" Not applicable

"..." Data not available or not reported 


\section{REFERENCES}

Arvis, J. F., Y. Duval, B. Shepherd and C. Utoktham (2013), "Trade costs in the developing world: 1995-2010", World Bank Policy Research Working Paper 6309. 